Anat. Labor. of Prof. H. SETO, Tohoku University, Sendai.

\title{
Histological Study on the Innervation of the Heart of Hedgehog.
}

\author{
針鼠心臟の神経分布飞関する組織学的研究。
} Yoshiya MATSUO 松尾由 也.

(Received October 4, 1956.)

In 1936, Prof. SETO of this laboratory carried out a study on the innervation of the human heart and succeeded in obtaining many interesting and thoroughly dependable observations. The results of his study, in particular, the part of it concerned with the vegetative innervation, was unreservedly confirmed later by STÖHR and HERMANN. On the sensory innervation of the human heart, AIBA made a supplementary study in 1954, and the problem of the innervation of the human heart has thus approached perfect solution. The innervation of the heart of various mammalia, also has been subjected to histological studies from old by SMIRNOW (1895, 1905), DOGIEL (1898, 1899), VALEDINSKY (1905), CAJAL (1906), MICHAILOW (1911), WOROVIEW (1926) and LAWRENTJEW (1929) among others, but little mentionable result has been attained. In 1953, however, SATO of this laboratory succeeded in making. interesting observations in his research on the innervation of the heart of $\operatorname{dog}$ and comparative study of his results with the findings obtained with human heart.

In succession of these illustrious forerunners, the author of this paper has been granted the opportunity of studying the innervation of the heart of hedgehog. The numerous materials available were first fixed in $10 \%$ neutral formol solution for a long time, then cut into $40 \mu$ transverse frozen section, stained with SETO's impregnation method in common use at this laboratory and made into large series of tissue preparations. These I subjected to thorough microscopic examinations, and studying the results, as SATO has done, from a comparative anatomical standpoint, have succeeded in achieving what $I$ report in the following.

\section{Individual Findings.}

The heart of a hedgehog is very small-sized, but in structure, of course, it shows no essential difference from that of man and other larger mammalia. But in microscopic examination of transverse sections of it, we find rather peculiar hedgehog-specific formation, so that it is sometimes very difficult to be sure on their orientation. Therefore, I made macro- 
scopic transverse sections of it to study its general structure and to serve as a guide in my histological observations, insuring inerrant orientation and localization. The heart of hedgehog being so very small, its transverse sections could be conveniently embedded in balsam on one slide apiece without further cutting up, a circumstance very helpful in obtaining accurate orientation.

What were to be specially mentioned in the histology of the heart of hedgehog were as follows. The epicardium is very thin and contains nearly no fat tissue, consisting entirely of a small quantity of loose connective tisste alone, and its surface is lined by a distinct one-rowed cubic epithelium. The paucity of fat tissue in the epicardium made the preparation of the frozen sections of the heart an extremely easy matter, as compared with that of the human heart. This epicardium was found in good development, however, at the origins of the aorta and the a. pulmonalis, its connective tissue passing over into the septum between them. The epicardium is somewhat thicker over the auricles (Fig. 1), but in the ventricles it is so thin that in some places the connective tissue is almost absent.

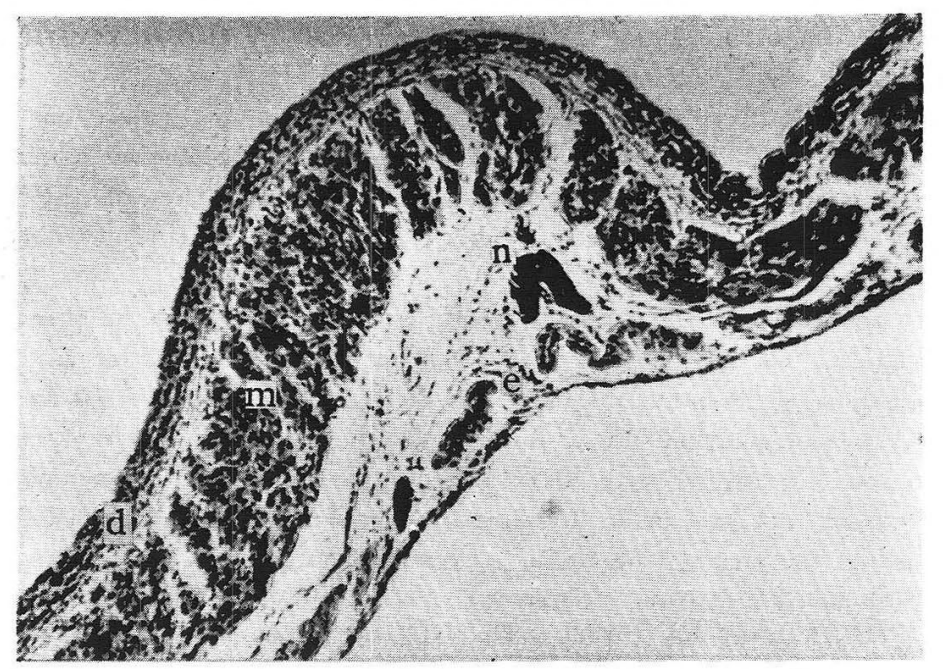

Fig. 1. Left auricle of a hedgehog heart. Transverse section. $n$ a nerve bundle of the GERLACH's plexus in the comparatively well developed epicarcardium $e$; $m$ myocardium; $d$ endocardium. SETO's impregnation. Photo $\times 76$.

The myocardium is composed of typical heart muscle fibres quite as in the human heart and that of other mammals. Among the musculature here, there were some fibres seemingly belonging to the specific PURKINJE's fibres, bnt it was rather difficult to distinguish between such 
fibres and the common heart muscle fibres. The development of the blood capillaries in the myocardium is probably much inferior to that in the human and the canine hearts.

The endocardium lining the auricles is comparatively thick (Fig. 1), but that of the ventricles is very thin. Even in the auricles, it is much thinner in their appendages. The endocardium in the auricles of hedgehog is comosed of a connective tissue rather rich in cells, as shown in Fig. 1. and smooth muscle fibres, as found in the human and the canine counterparts, are scarcely, if ever, found. The inside of the endocardium is lined by quite typical one-rowed endothelial cells, in the auricles and the auricular appendages. In the ventricles, it is extremely thin, consisting of very thin or almost unascertainable connective tissue layer and a layer of flat endothelial cells, and of course, never containing smooth muscle fibres.

Thus, the heart of hedgehog is not different from that of man and other mammals in essence, but it is noteworthy that its epicardium and endocardium are particularly simple in construction.

As the heart of hedgehog is very small, as mentioned above, the formation of the so-called GERLACH's plexus cordis found in the epicardium in the auricles was grasped very distinetly. This plexus was found to consist in an extension of the plexus foremed by a conglomeration of automatic nerves (sympathetic and parasympathetic nerve bundles) running through the septal connective tissue between the a. pulmonalis and the

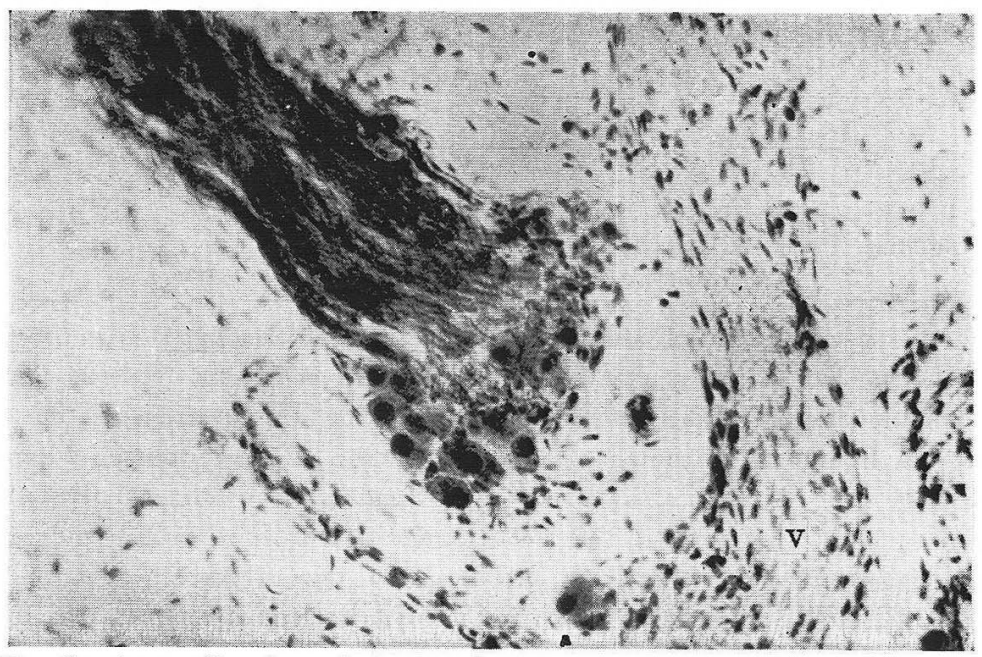

Fig. 2. A ganglion formed along a thick nerve bundle of the GERLACH's plexus found in the epicardium around the radices of the aorta and the a. pulmonalis in the dorsal side in a hedgehog heart. $v$ small vein. Details in the text. Same staining. Photo $\times 100$. 
aorta and the ganglia of varying size dispersed therein. That is to say, the plexus formed between the two major arteries descends peripheralwards to spread out into the epicardic connective tissue strongly developed around the origins of the arteries, thus to become the GERLACH's plexus. The ganglia in this plexus are formed along the nerve bundles in the epicardium surrounding the aorta and the pulmonalis, rather than between the two arteries (Figs. 2 and 3). Thus, the GERLACH's plexus cordis is merely an extension of the plexus formed between the aorta and the a. pulmonalis, so that these two plexuses are identical formations. This identity of the two plexuses is presumably a principle common to all mammals.

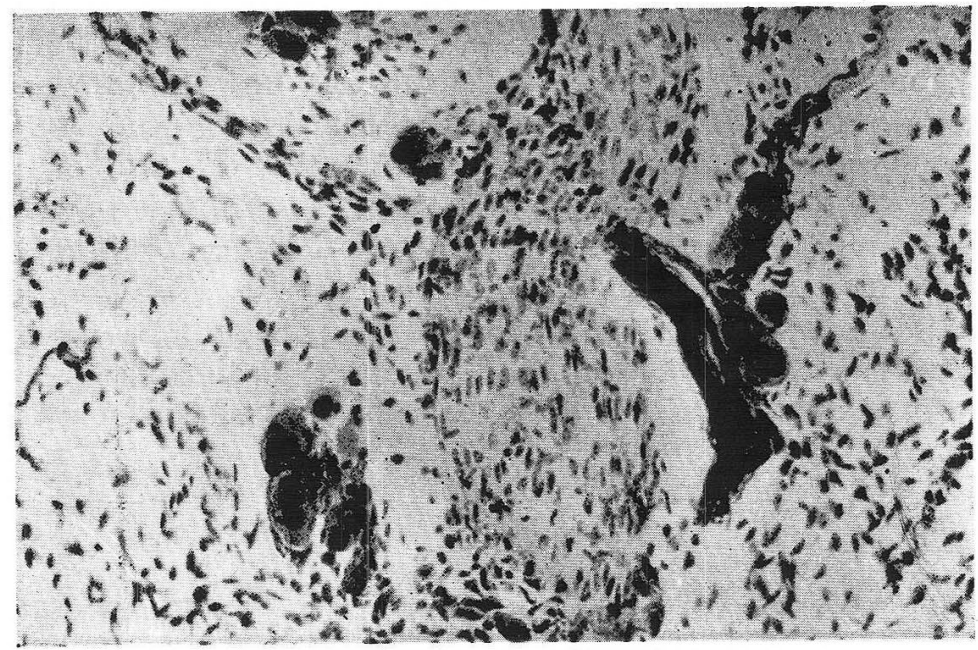

Fig. 3. Sporadically distributed small ganglia formed alog the small nerve bundles of the GERLACH's plexus found in the same place as in Fig. 1. Details in the text. Same staining. Photo $\times 100$.

The development of this plexus, interestingly enough, is in proportion with that of the connective tissue in the epicardium. So, the plexus is best developed in the epicardium surrounding the origins of the two arteries, but in the thinner epicardium of the auricles, the development abruptly falls off, only a few small nerve bundles being found in straggling courses there (Fig. 3). In the yet thinner epicardium of the auricular appendages, the nerve bundles become even fewer, and in that of the ventricles, wherein the connective tissue layer is almost absent, any nerve bundles are hardly found. The nerve bundles in the ventricles consist in those branching out directly into the myocardium from the plexus in the auricular epicardium, in particular, in the epicardium around the origins of the aorta and the pulmonary artery. 
As detailed in the above, the GERLACH's plexus in the heart of hedgehog is particularly well developed at the origins of the a. pulmonalis and the aorta, so that the formation of its ganglia is also limited to these parts. This is very different from what has been observed in the human heart (FRANCILLON, SETO) or in that of dog (SATO), wherein the ganglia are found formed in many parts of the auricles. Such ganglia are never found in the ventricular epicardium, either in hedgehog or in man and $\mathrm{dog}$, due to the extremely weak development of the epicardium in the ventricles.

The GERLACH's plexus in hedgehog is much poorer in construction than that in man and dog, and the SETO's classifications of the plexus into the fundamental, the secondary and the tertiary plexus is much blurred here. The plexus sends out fine nerve bundles into the myocardium of the auricles and the ventricles, which undergo frequent ramification in the myocardium and diffuse into the endocardium as well.

The GERLACH's plexus, as stated above, consists of non-medullated fine sympathetic and parasympathetic fibres, in the main, but contains besides some medullated thick sensory fibres too, though in a smaller number than in man and dog. These sensory fibres are presumed chiefly to be derived from the vagal nerve, but it is possible that some of them originate in the cervical or the thoracal nerves. The distinction between the sympathetic and the parasympathetic nerve fibres was histologically impossible.

The ganglia in the GERLACH's plexus are generally of small type, the largest ones containing only 20-25 nerve cells in one section, the majority consisting only of 5-10 cells. As shown in Fig. 3, grotups of only a few cells are also found here and there, and nerve cells in solitary existence are rather often too (Fig. 5). Such typical connective tissue capsulated ganglia, as found in man and dog, are extremely rare in hedgehog, most of the ganglia here being non-capsulated. The size of the ganglia is not always in correspondence with that of the nerve bundles connected with them.

The nerve cells forming the ganglia in the GERLACH's plexus of hedgehog are much simpler than those of dog, not to speak of the cells of man. So, many of the nerve cells are found to be very indistinct in their multipolarity or appear to be apolar, unbecoming for sympathetic nerve cells, but upon closer examination, these cells are found to have extremely fine nerve processes, and not a few of them to send out clearcut and multiple nerve processes (Fig. 4), so that the intracardiac ganglion cells of hedgehog should be taken to belong to the sympathicus without doubt. Among them, some cells are found to resemble bipolar nerve cells as found in the cerebrospinal ganglia, as shown in Fig. 5, but since these 


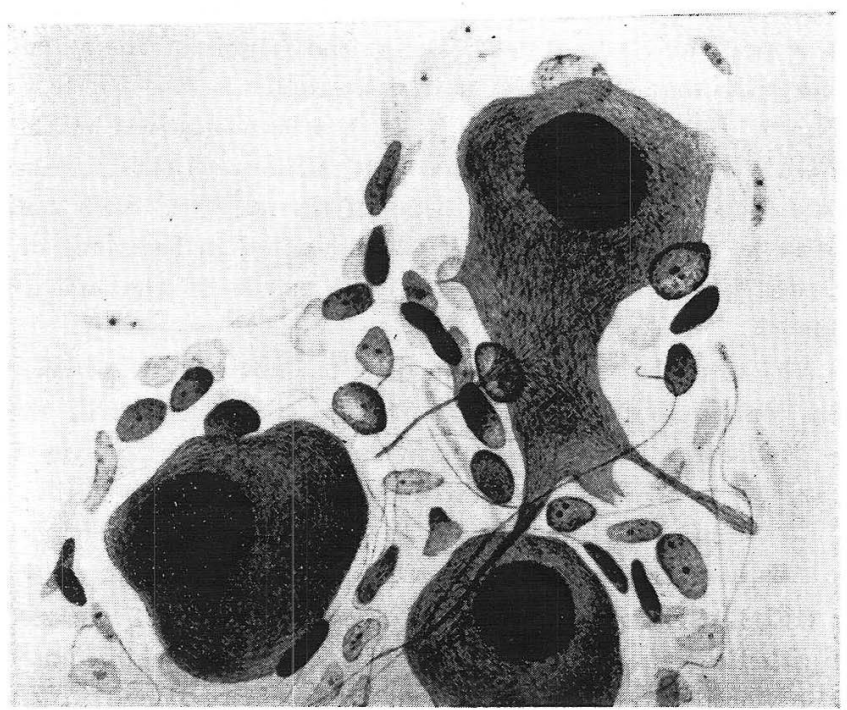

Fig. 4. Ganglion cells in a small ganglion found in the epicardium surrounding the radix of a. pulmonalis in a hedgehog heart. Details in the text. Same staining. $\times 800$, reduced to $2 / 3$.

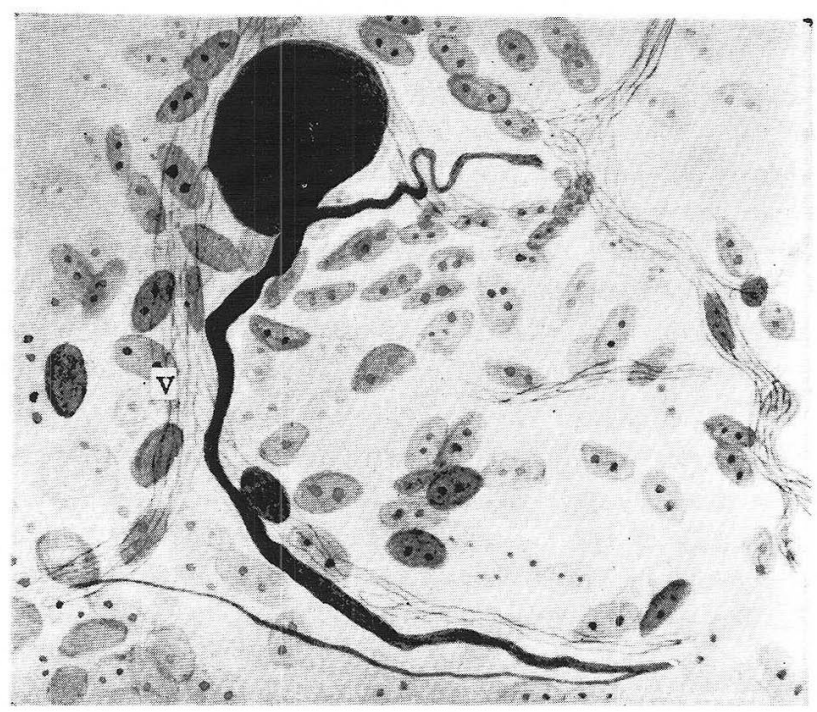

Fig. 5. A small ganglion cell found in the epicardium surrounding the origin of the aorta of a hedgehog heart. $v$ fine vegetative fibres. Details in the text. Same staining. $\times 800$, reduced to $3 / 4$. 
also are found to have 2-3 short processes upon closer scrutiny, they are not sensory in nature, but are merely sympathetic nerve cells with 2 long nerve processes or axis cylinders.

Thus, the intracardiac ganglion cells of hedgehog are not destitute of their multipolarity characteristic of sympathetic cells, but the development of their nerve processes is much weaker than that of the processes of the same cells in man (SETO) and dog (SATO), and the cells resemble the sympathetic cells found in the various organs of human embryos in the middle stage (TAKAHASHI, UTSUSHI, NISHIMURA). So, these cells are clearly of the infantile type, and the classification of them into DOGIEL's types I and II cells is impossible. NUMATA also has recently reported on the innervation of the lung of bat, and pointed out therein the very low differentiation of the intrapulmonary sympathetic cells, as in the case of the intracardiac sympathetic cells in my hedgehog. And in concurrence with the opinion of NUMATA, I believe that in all probability the degree of the development of such sympathetic nerve cells represents the measure of the evolution of the animal.

Up to about 1930, the terminations of the vegetative nerve fibres too were accepted to form free endings as do the motor and the sensory fibres, but STÖHR, REISER and BOEKE have established by their studies utilizing the modern silver impregnation methods that the vegetative fibres never end freely, but always form a widely spreading large reticular system. This end net-work was named the vegetative terminal reticulum by STÖHR and the sympathetic ground plexus by BOEKE. The ubiquitous formation of the vegetative net termination has been since then endorsed by SETO and his many disciples of this laboratory and many other researchers of the younger generation. In particular, SETO has exploded the theory advocated by SMIRNOW, MICHAILOW, LAWRENTJEW and BOEKE maintaining that the nerve fibres belonging to the sympathicus and the parasympathicus end in respectively very dissimilar free terminations, in his study on the human heart, in pointing out that the fibres of both these systems end in common in STÖHR's terminal reticula. Such a terminal mode of the vegetative fibres in the heart established by SETO has been confirmed by STÖHR and HERMANN later on and more recently, SATO of this laboratory has found the same mode of termination in the dog heart.

The study of the terminal mode of the vegetative nerve fibres has been since then much promoted by many researchers in Europe, including of course STÖHR and BOEKE, and detailed discussions have been published on the subject, but the opinions are not yet in sufficient reconcilation. Some of the neurologists, not too few in number, asseverate even today that the vegetative fibres end in free endings as given in former 
reports.

In general, the terminal reticula supplied to cells consist of net cords formed by finest neurofibrils incapable of further splitting. These cords always undergo ramification and mutual anastomosis with other cords everywhere and thus form one huge reticular system of vegetative terminations. Such terminal reticula were very distinctly demonstrated in $\mathrm{my}$ sections of the hedgehog heart too (Figs. 6, 7 and 10).

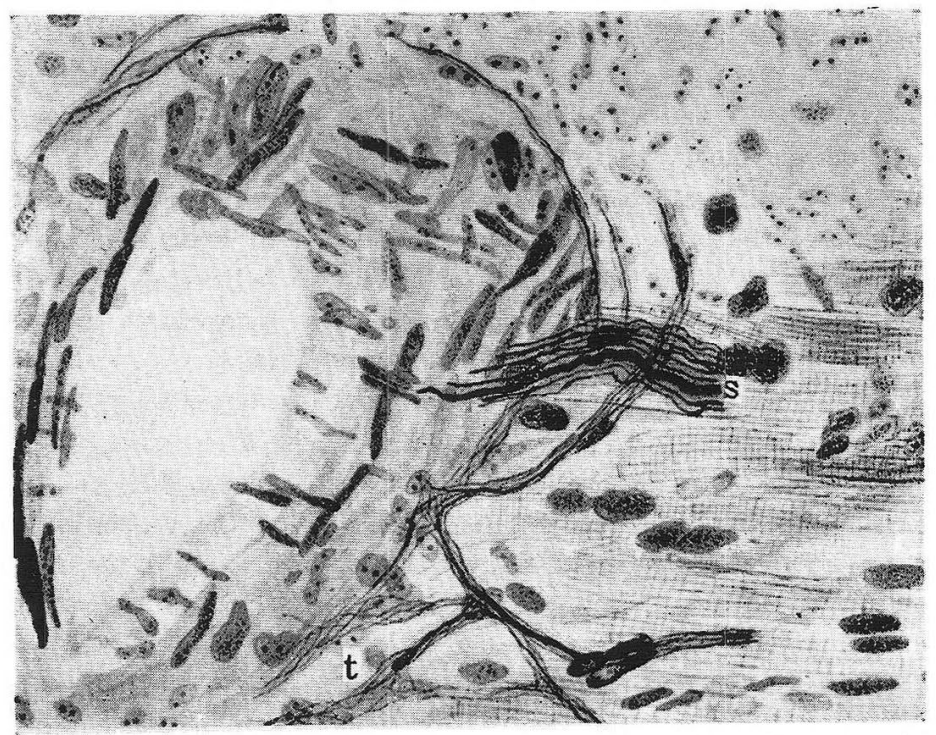

Fig. 6. Nerve bundles around a small artery running between the epicardium and the myocardium of the left auricle of a hedgehog heart. $s$ a thick sensory fibre accompanied by fine vegetative fibres; $t$ terminal reticulum. Same staining. $\times 320$, reduced to $3 / 4$.

The structure and the relation to the supplied cells of these terminal reticula found in the heart of hedgehog are in approximate agreement with what has been published in many reports from this laboratory. So, in my ideally impregnated preparations, I have never found such side branches allegedly running from the terminal cords into the supplied cell bodies, as in controversy among the European researchers. Accordingly, a plasmatic connection between the cords and the supplied cells seems not possible, and I am of the opinion that the transmission of the stimulations from the terminal reticula to the tissue cells is effected by the endocrine substances secreted by the syncytial neuroplasma cells (SCHWANN's cells) contained in the cords, and that this substance permeates into the supplied cells to excite them. 


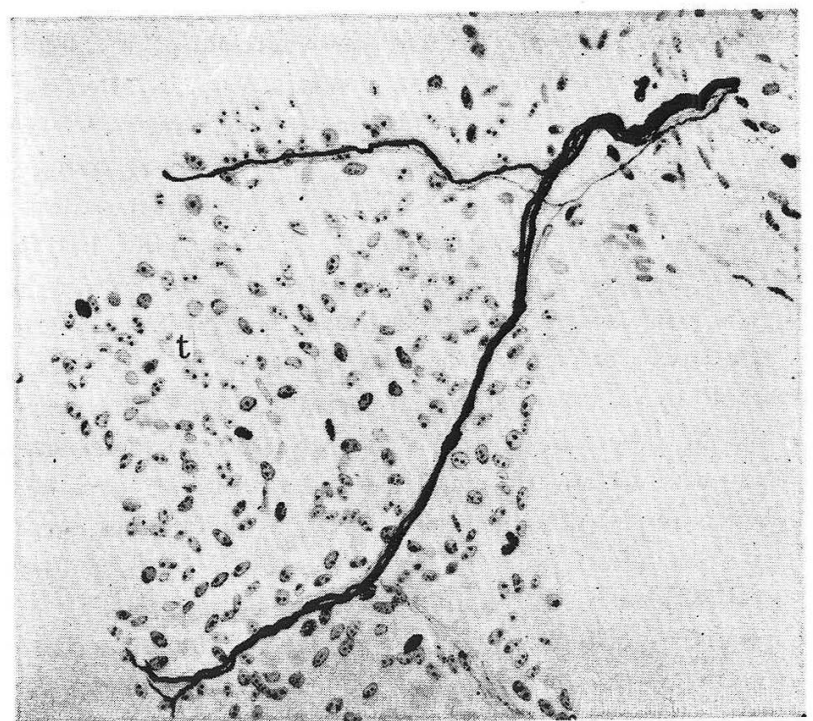

Fig. 7. Simple branched sensory termination accompanied by fine vegetative fibres found in the epicardium of the left auricle of a hedgehog heart. $t$ terminal reticulum. Details in the text. Same staining. $\times 320$, reduced to $2 / 3$.

Thus, the vegetative terminal reticula never send out branches into the supplied cells but only run along their surfaces. These reticula are in very typical formation in every part of the heart of hedgehog, in the epicardium (Fig. 7), in the walls of the blood vessels (Fig. 6) and in the myocardium as well (Fig. 9). We cannot concur with the existence of fine nerve elements running into the supplied cells as postulated by many neurologists. Probably, such fine elements are nothing but artefacts produced by the extreme restiveness of silver used in impregnation.

SMIRONOW (1895) was the first to broach the existence of sensory terminations in the heart. He described rather complex branched terminations found in the heart wall of amphibians and complex arborized terminations in the epicardium and the endocardium of rat and cat. Next, DOGIEL (1898) expressed agreement with SMIRNOW's observations. MICHAILOW $(1907,1908)$ also reported the existence of very complex-formed capsulated and non-capsulated glomerular and branched terminations in the endocardium and the pericardium of horse. But since the above findings were made with methylene blue stained preparations, they were subject to later revision. LAWRENTJEW (1929) asserted that complex arborized terminations were found in his silver impregnated preparations of the endocardium of dog and cat and LAWRETJEW and GURWITSCH-LASOWSKAYA (1935) that they found a kind of sensory termination in the con- 
nective tissue between the atrium and the ventricle of rat. SETO (1936), using his silver impregnation method, made a very detailed and reliable report on the existence of sensory terminations of various types in the human atria cordis and AIBA (1954) made very interesting supplementary observations on the same subject. SATO (1953) found multiform sensory terminations in the atria of canine heart, and studying his findings in comparison with the past reports on the innervation of animal hearts and that on human heart by SETO, succeeded in making very interesting observations. He says that a rather large number of myelinated sensory fibres are found to penetrate into the atria of dog, forming their terminations in all the layers of the atria and in structure much simpler than those in the human heart. He classified these terminations into the types of unbranched, simple branched and Type I of terminations of nerves connected with the blood pressure lowering reflex. He also found simple branched terminations in the wall of the coronal arteries.

In the heart of hedgehog too, comparatively numeroùs sensory fibres probably originating in the vagus are found, as stated above. The distribution of these fibres is seemingly limited to the atria, as in the case of man (SETO, AIBA) and does not to extend into the ventricles. The terminations of these fibres are formed in the epicardium, myocardium as well as the endocardium, but the majority is found in the myocardium while the endocardium has the smallest number of them.

As the sensory fibres consist of myelinated thick fibres, they can be quite readily distinguished from the non-myelinated vegetative fibres (Figs. 8 and 9), and since their terminations form free endings consisting of thick fibres, their distinction from the vegetative terminal reticula is also an easy matter.

These sensory terminations are incomparably simpler in construction than those of man, and much simpler than those of dog (SATO) too. Thus, these terminal formations are probably most ingeniously designed in the human heart, losing in complexity in the heart of lower animals. Thus, in the human heart are found very complexly formed typical sensory terminations Type I concerned with the blood pressure lowering reflex, but in $\mathrm{dog}$, the terminations of this type are much more simplified, while in my sections of the heart of hedgehog, no such peculiarly formed terminations were ever found, and indeed, complex terminations of any type were not to be observed here, the terminations consisting mostly in unbranched and less frequently in simple branched terminations.

The unbranched type of sensory terminations is the simplest of all sensory end apparatus. In such a termination, a thick myelinated fibre, after losing its myelin sheath, takes a characteristically winding course while showing change in size and ends in a sharp point. Such termina- 


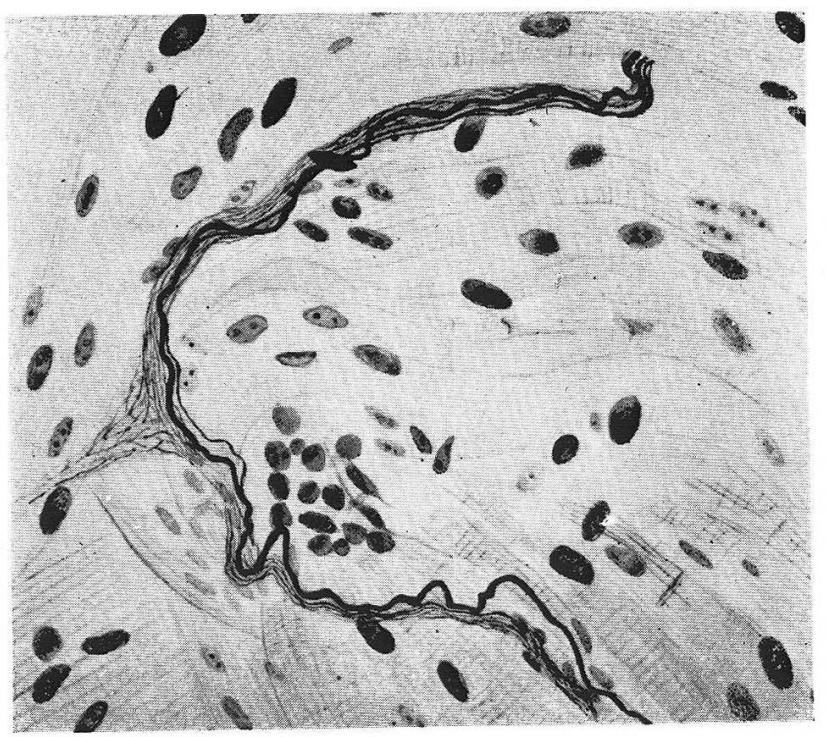

Fig. 8. Small nerve bundle composed of fine vegetative fibres and a thick sensory fibre running in the myocardium of the right auricle of a hedgehog heart. Same staining. $\times 320$, reduced to $2 / 3$.

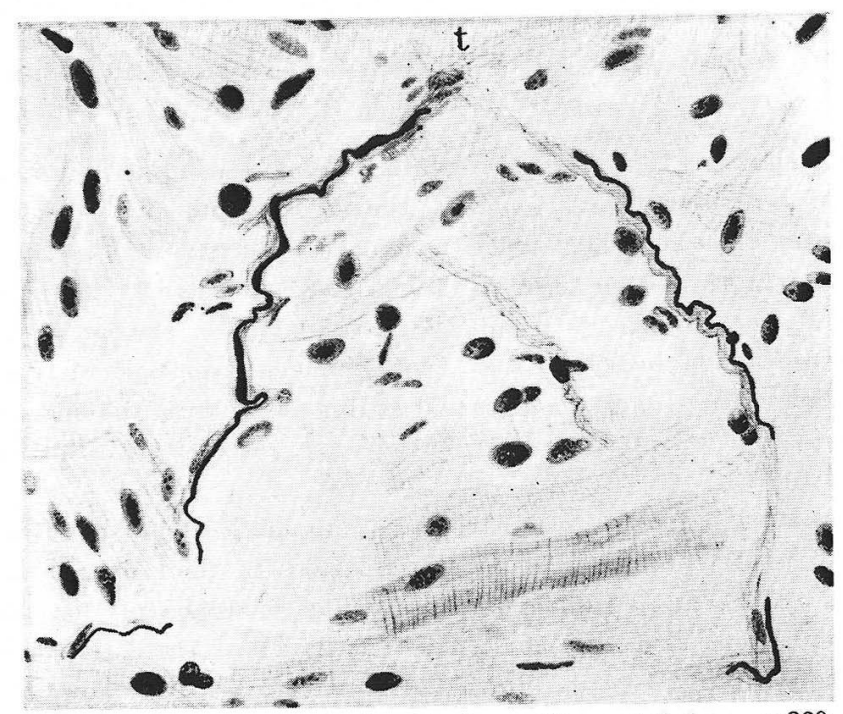

Fig. 9. Ditto. $t$ terminal reticulum. Same staining. $\times 320$, reduced to $3 / 4$. 
tions are found in all the cardiac layers of the atria cordis, but in the largest number in the myocardium.

Fig. 10 shows for example a typical unbranched sensory termination

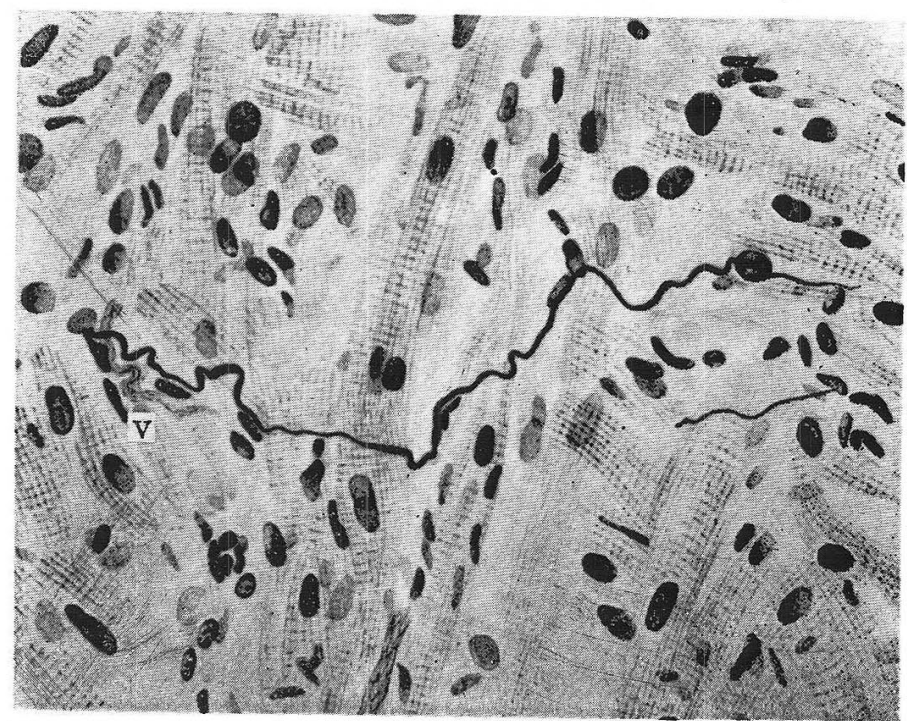

Fig. 10. An unbranched sensory termination ending in a sharp point found in the myoeardium of the right auricle of a hedgehog heart. $v$ fine vegetative nerve fibres. Details in the text. $\times 320$, reduced to $2 / 3$.

of a fibre showing change in size while running a winding course characteristic of a sensory fibre, found in the myocardium of the left auricle of the heart of a hedgehog. Such terminations of simplest structure are often found in the canine atria (SATO, Fig. 8), but hardly in the human heart. Unbranched sensory terminations are found in the epicardium and the endocardium of hedgehog too. Such simple terminations of fibres running characteristic winding courses and ending sharply in the endocardium of the left auricle and the right auricle are respectively illustrated in Figs. 11 and 12.

The simple branched terminations ending in 2-3 branch fibres are nearly identical to the unbranched terminations in their nature and running courses of the terminal branches which end sharply or bluntly. Such terminations also may be seen in any layer of the atria cordis, but in the endocardium they occur only very rarely. Fig. 13 shows a simple branched termination found in the myocardium of the left auricle, of which the running courses of the branches are not different from that of the unbranched fibres shown in Fig. 10. Fig. 7 shows a branched termination 


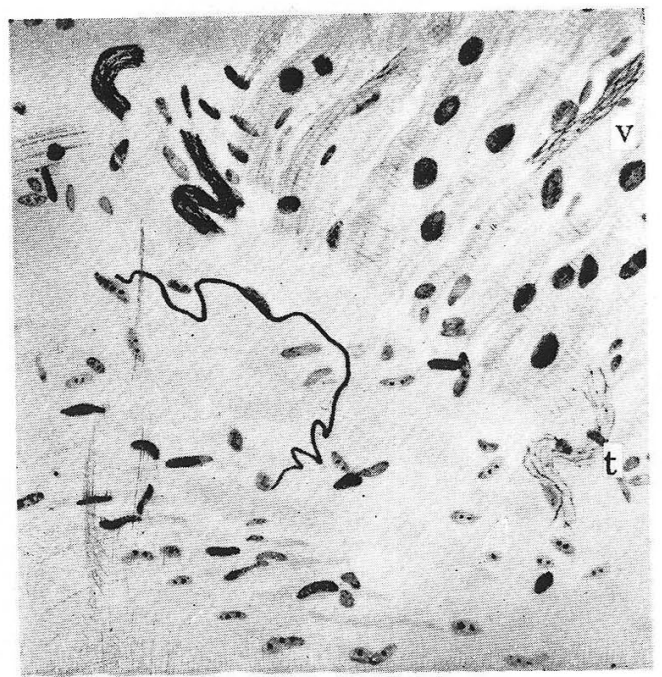

Fig. 11. An unbranched sensory termination ending in a sharp point found in the endocardium of the right auricle in a hedgehog heart. $v$ fine vegetative nerve bundle; $l$ terminal reticulum. Same staining. $\times 320$, reduced to $4 / 5$.

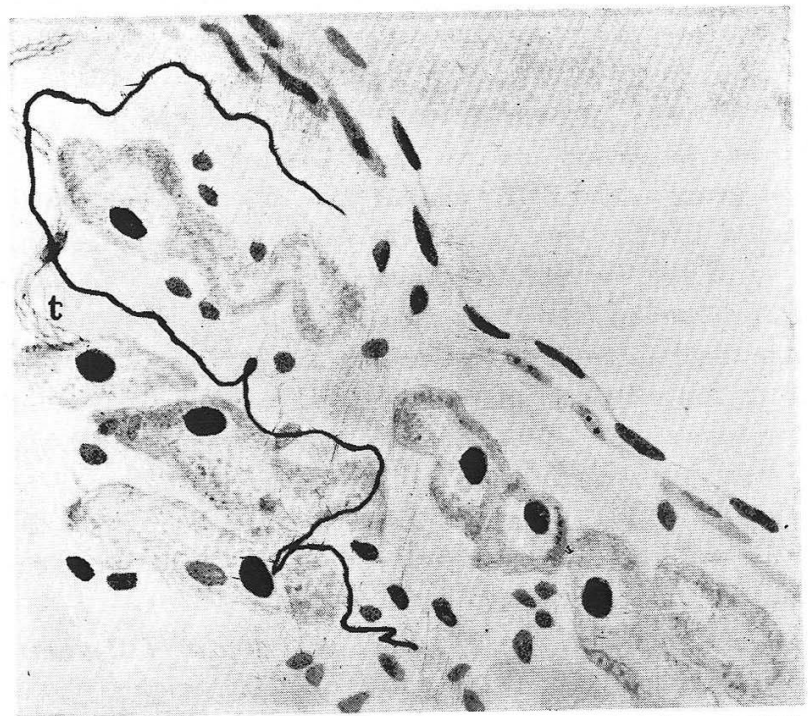

Fig. 12. Ditto. $l$ terminal reticulum. Same staining. $\times 320$, reduced to $4 / 5$. 


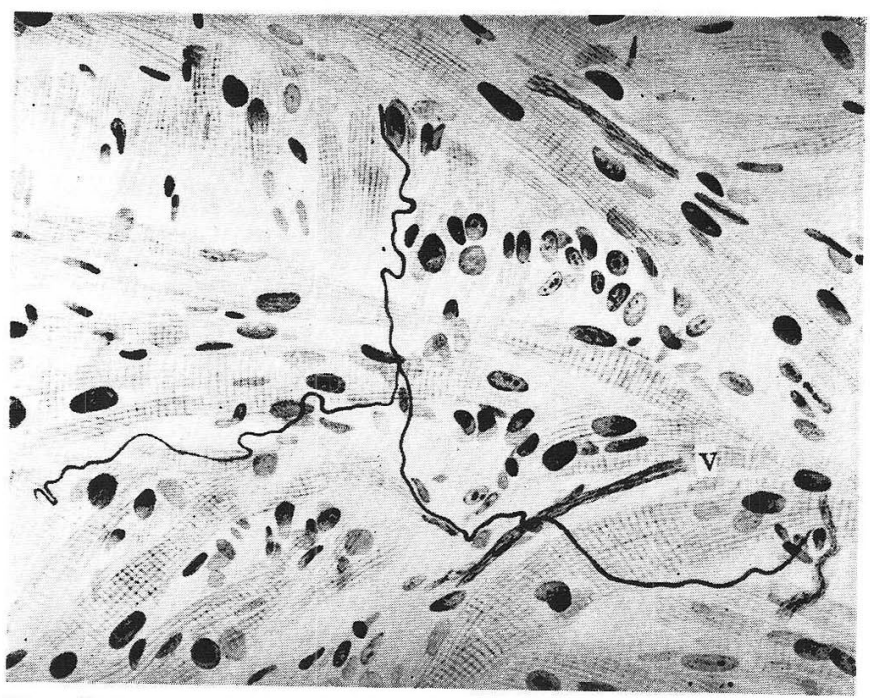

Fig. 13. A simple branched sensory termination found in the myocardium of the right auricle of a hedgehog heart. Details in the text. $v$ fine vegetative fibres. Same staining. $\times 320$, reduced to $2 / 3$.

found in the epicardium of the left auricle. Here, a single very thick sensory fibre finally branches out into several rami which all end in sharp points. It must be noted that these terminal fibres do not run perceptibly winding courses and accompany fine vegetative fibres.

SATO has frequently observed branched sensory terminations around the coronal arteries, and SETO and AIBA a fairly large quantity of complex branched terminations around the small veins running through the myocardium of the atria of the human heart. I have found not rarely sensory fibres running along the blood vessels in the heart of hedgehog too, though those forming their terminations on the walls of the vessels seemed to be few. To my interest, I found a markedly winding sensory termination consisting of 2 or 3 branch fibres around small blood vessels in the myocardium near the origin of the aorta in the upper part of the left ventricle (Fig. 14). From this finding, it can be inferred that sensory terminations are formcd in the ventricles of the heart in hedgehogs, though, it may be, only on a few exceptional occasions.

Sensory terminations were found in the externa of the aorta and the a. pulmonalis, especially in the vicinity of their origins, certainly in a small number only. Their terminal mode is also very simple, only unbranched and simple branched terminations being found. In Fig. 15 is illustrated a simple branched termination of a thick sensory fibre which 


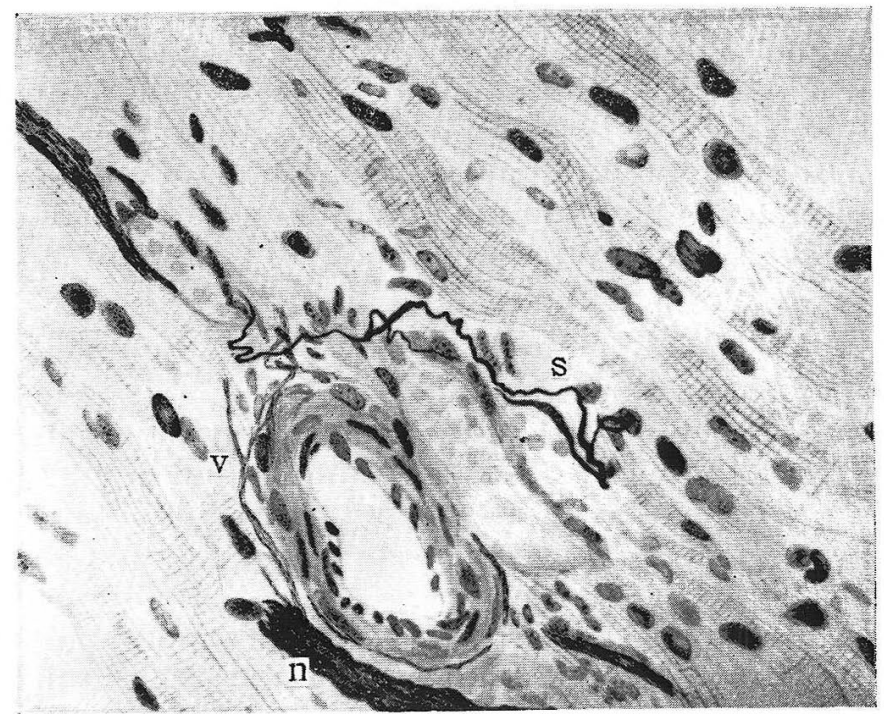

Fig. 14. A simple branched sensory termination $(s)$ formed along the small blood vessels running in the myocardium of the left ventricle near the origin of the aorta in a hedgehog heart. $n$ small nerve bundles; $v$ fine vegetative fibres. Same staining. $\times 320$, reduced to $2 / 3$.

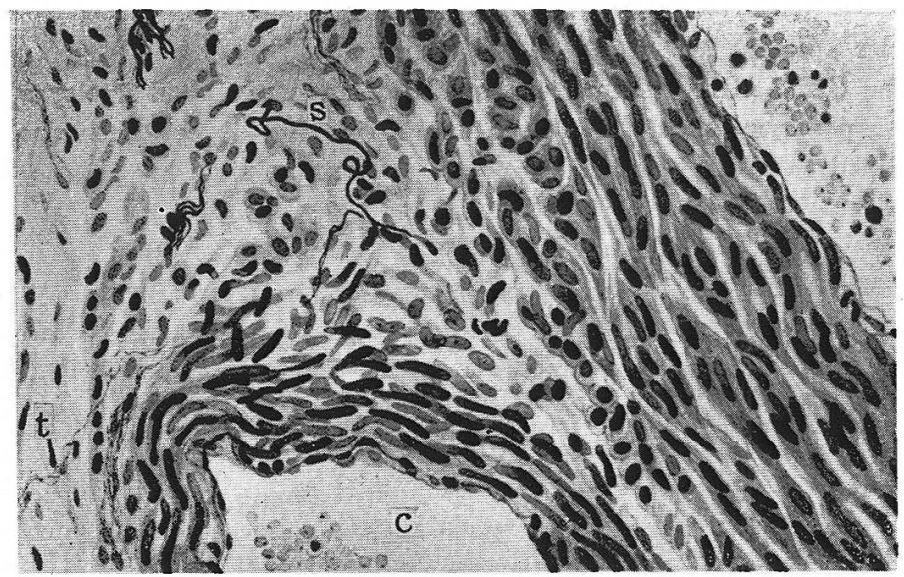

Fig. 15. A simple branchd sensory termination (s) found in the externa in the original part of the aorta of a hedgehog heart. $c$ a. coronaria cordis; $l$ vegetative terminal reticulum. Same staining. $\times 180$.

upon running into the adventitia of the aorta and taking a characteristic winding course, branches out into 2 fine branches which without penetrating 
into the media end in sharp points outside it.

As detailed in the above, sensory fibres may be found distributed in the heart of hedgehog, especially, in its atriae cordis. Their terminations, however, are always of the simplest types, and no such complex formations, as the glomerular terminations and the specific arborized terminations connected with the blood pressure lowering reflex as found in the human heart could be found in the heart of this animal.

\section{Summary.}

The heart of hedgehog being very small in size, the structure of the so-called GERLACH's plexus cordis could be grasped very readily. This plexus so much poorer in development than that in man or dog has been found to represent an extension of the plexus formed between the aorta and the a. pulmonalis and containing ganglia at various points, is developed best in the thickest and best-developed part of the epicardium encircling the origins of the two large arteries above. In the worse-developed epicardium of the auricles and in that of the auricular appendages still poorer in development, the plexus abruptly falls off in development. The epicardium of the ventricles is too thin for nerve bundles to run therein. The ganglia are found only along the nerve bundles in the epicardium surrounding the origins of the aorta and the a. pulmonalis, where the plexus is in good development. Such a parallelism between the development of the GERLACH's plexus to that of the epicardium is probably common to all other animals too.

The GERLACH's plexus is composed of non-medullated fine sympathetic and parasympathetic fibres in the main, but it contains also some medullated thick sensory fibres mostly perhaps originating in the vagal nerves.

The ganglia found in this plexus are mostly of non-capsulated type, even the largest ones containing only from 20 to 25 cells. These cells are much poorer than those of man and dog in development, barely showing their characteristic multipolarity and clearly belonging to the infantile stage, for they rather resemble the sympathetic cells found in human embryos of middle stage than anything else. Of course, the distinction of these cells into the DOGIEL's types I and II is not clear. The development of these sympathetic cells seems to offer a measure to estimate the level of evolution of the animal.

The GERLACH's plexus sends out fine nerve bundles into the myocardium of the auricles and the ventricles. These bundles, after repeated ramifications in the myocardium, finally spread out into the endocardium. The autonomic fibres, both the sympathetic and the parasympathetic, never end in separate free endings of their own but always pass over into 
the terminal reticula (STÖHR) common to both the systems, as SETO and SATO have already reported. Such terminal reticula are conspicuously in formation in all the parts of the three layers of the heart and stand in contact control over the supplied cells. No plasmatic connection between the cells and the reticula through the side-branches of the latter penetrating into the bodies of the supplied cells can be demonstrated. Accordingly, it seems that the transmission of stimuli from the reticula to the cells is effected by the excitation of the latter by the endocrine chemical substances secreted from the SCHWANN's cells in the reticula and permeating into the supplied cells.

The area of distribution of sensory of fibres in the heart of hedgehog chiefly lies in the auricles and the auricular appendages, as in the human and dog hearts. Their terminations are found in all the layers, but the number is much smaller in the appendages than in the auricles. Although in an extremely small number, sensory terminations ware found around the blood vessels running through the myocardium of the left ventricle at the origin of the aorta too.

The sensory terminations seen in the heart of hedgehog are incomparably simpler in construction than those in man and even far simpler than those in dog. Such complexly formed ones as the complex specific terminations concerned with the blood pressure lowering reflex, glomerular terminations or complex branched terminations, so conspicuous in the human and the canine hearts, are never to be found in the heart of hedgehog, where the terminations consist in unbranched terminations and a few simple branched terminations alone. In these, the terminal fibres show frequently change in size while running winding courses characteristic of sensory fibres and end sharply. In the endocardium, branched sensory terminations were scarcely found.

Sensory fibres running along the small blood vessels in the auricles are not rare, but their terminations formed around these vessels were very scarce. A small number of unbranched and simple branched terminations were found in the externa of the aorta and the a. pulmonalis near their origins. The terminal fibres of these terminations were never found to penetrate into the media.

\section{内 容自抄.}

針鼠心臓内の Gerlach 氏神経叢は人や犬のものよりは遙かに劣勢な発達 を示し, 大動脈と肺動脈との間飞形成される神経節所有の神経叢の続きで 表わされ, 両動脈起始部を取巻く最強力な発達を示す心房外膜内で最も著 明な形成を示す。としてょり発達の弱い一般心房の外膜, 更飞発達劣勢な

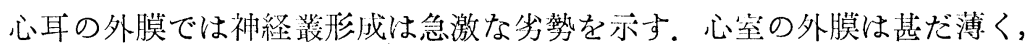


為に神経束は証明されない, 又神経節も神経叢の発達に比例し, 其大多数 は大動脈と肺動脈起始部の心房外膜の神経埿飞見られる，以上の法則は他 動物の心蔵飞も当てはまるものと思われる。

Gerlach 氏神経叢は交感及び副交感線維から成るが，尚招恐らく迷走神 経由来の知覚線維をも含む. 本叢の神経節の発達も人や犬と於けるより は甚だ劣勢で且つ神経細胞も多極性を辛うじて表わしていると過ぎず，何 れも人胎児に見られる幼若型を思わしめるものである．此交感神経細胞の 発達状態は動物の進化の尺度を示すかの様と思われる.

Gerlach 氏神経叢からは心房と心室の筋膜飞微細枝が出る，之等は其中 で再三分岐吻合の後，内膜飞迄拡散する，交感，副交感両線維怯相異る遊 離終末に終る事なく，共通性のStöhr 氏終網に移行し，之は心蔵各層内の 被主幸細胞飞対し，接触的主宰関係を示す。

針鼠心臟に於ける知覚線維の分布範囲は人や犬に於けると同様，概ね心 房及び心耳に限られていて，其終末は各層に形成されるが，心耳では心房 に於けるよりは量的に遙かに少い，尚括甚だ稀に大動脈起始部に於ける心 室の筇層内を走る血管壁にも知覚終末が発見された。

針鼠心蔵内に見られる知覚終末は人の場合には比す可くもなく単純に構 成される. 即ち, 血圧下降反射飞関する複雑な特殊終末, 糸氹終末或は複 雑性分岐終末等は何処飞も見られず，終末の多くは非分岐性，少数は単純 性分岐性終末で表わされると過ぎない，尚括心房内膜内㤋分岐性終末は 証明されない。

心房内で小血管に沿って走る知覚線維は稀ならず発見されたが，小血管 そ終る知覚終末形成は極めて稀に見られたに過ぎない。尚お大動脈队灭び肺 動脈の起始部飞近く其外膜内飞形成される非分岐性及び単純性分岐性終末 は証明されたが，其終末枝は中膜迄は入らない。

\section{References.}

Ábrahám: Z. Zellforsch. 31 (1940). - Aiba : Arch. hist. jap. 6 (1954). Boeke : Z. mikr.-anat. Forsch. 33 (1933), 34 (1933), 38 (1935), 46 (1939). - Acta anat. 8 (1949). - Cajal : Erg. Anat. 16 (1906). - Dogiel: Arch. mikr. Anat. 52 (1898), 53 (1899). - Francillon : Z. Anat. 85 (1928). - Hermann : Z. Anat. 114 (1950). - Kölliker: Handbuch der Gewebelehre des Menschen. Leipzig, W. Engelmann, 1902. - Lawrentjew : Z. mikr.-anat. Forsch. 16 (1905). - Lawrentjew a. Gurwitsch-Lasowskaya : Z. mikr.-anat. Forsch. 21 (1930). - Michailow: Anat. Anz. 31 (1907); 32 (1908). - Folia neuro-biol. 5 (1911). Nishimura : Arch. hist. jap. 6 (1954). - Numata : Arch. hist. jap. 9 (1956). - 
Reiser: Z. Zellforsch. 15 (1932), 22 (1935). - Sato: Tohoku J. exp. Med. 59 (1954). - Seto: Arb. Anat. Inst. Sendai. 19 (1936), 20 (1937). - Smirnow : Anat. Anz. 10 (1895), 18 (1900). - Anat. H. 27 (1905). - Stöhr : Z. Zellforsch. 21 (1934), 27 (1937). - Lehrbuch der Histologie und mikroskopische Anatomie. Berlin, J. Springer, 1951. - Erg. Anat. 34 (1952). - Sunder-Plassmann : Z. Anat. 93 (1930). - Z. Neurol. 147 (1933). - Takahashi : Arch. hist. jap. 10 (1956). - Utsushi : Tohoku J. exp. Med. 60 (1954). - Worobiew : Med. Klin. 22 (1926). - Valedinsky : Anat. H. 27 (1905). 